\title{
The Relationship between EFL Teachers' Critical Thinking Skills and Vocabulary Learning Strategy Instruction across Gender
}

\author{
Mehrak Rahimi (Corresponding author) \\ Shahid Rajaee Teacher Training University, Lavizan, Tehran, 1678815811, Iran \\ Tel: 98-21-2297-0035 E-mail: mehrakrahimi@yahoo.com \\ Maryam Soryani \\ Shahid Rajaee Teacher Training University, Lavizan, Tehran, 1678815811, Iran \\ Tel: 98-21-2297-0035 E-mail: soryani77@yahoo.com
}

Received: 21-09-2013

doi:10.7575/aiac.ijalel.v.3n.1p.107
Accepted: 24-10-2013

Published: 01-01-2014

URL: http://dx.doi.org/10.7575/aiac.ijalel.v.3n.1p.107

\begin{abstract}
The purpose of this study was investigating the relationship between Iranian EFL teachers' critical thinking skills and teaching vocabulary-learning strategies to their students. Additionally, it explored the difference of the strength of correlation between critical thinking skills and vocabulary learning strategy instruction across gender. California Critical Thinking Test- form B and Yu-Ling's inventory of teaching vocabulary-learning strategies were administered to 90 Iranian EFL teachers. The results showed that strategy instruction significantly and inversely correlated with analysis $(\mathrm{r}=-.27)$, inference $(\mathrm{r}=-.22)$, and inductive reasoning $(\mathrm{r}=-.3)$ skills, while the correlation was not significant considering evaluation $(\mathrm{r}=-.11)$ and deductive reasoning $(\mathrm{r}=-.089)$ skills. Moreover, the difference between correlation of vocabulary learning strategy instruction and inference skill was statistically significant when male and female participants were compared $\left(\mathrm{Z}_{\mathrm{obs}}=2.24\right)$.
\end{abstract}

Keywords: critical thinking skills, vocabulary, learning strategies, EFL teachers

\section{Introduction}

The way we think affects all aspects of our private and social life and education is not an exception. Human beings think differently and teachers who have key roles in education do so. Recently proper attention has been given to the ways teachers think (Calderhead, 1987) and now teaching is more characterized as a thinking activity (Richards \& Farell, 2005).

Critical thinking is an important concept in education and is generally defined as the ability to think rationally and make good decisions in doing something or believing something (Ennis, 2011). Critical thinking includes special skills to identify a problem, analyze it, and make inferences to solve it. It also requires judging the validity and reliability of assumptions and sources of data, making decisions based on specific reasoning criteria, and applying inductive and deductive logic (Pithers \& Soden, 2000; Diestler, 2001).

In the information age, thinking plays an important role in one's success (Huitt, 1998) as a person who thinks critically can ask suitable questions, gather relevant information, and come to reliable conclusions about the world and thus live more successfully (Center for Critical Thinking, 1996). Meaningful education has to prevent learners from unreflective learning and provide them with the tools necessary to understand the world they live in (Chaffee, 1985). In this framework, teaching is defined as "a complex interaction including subject matter, content, teacher and student characteristics, pedagogy, resources, and learning context" (Campbell, 2000, p. 50). Therefore, in highly technical society which is developing moment by moment, and with students who are getting educated in this society, there is a need to teachers who can address students' needs and the time of teachers who blindly follow the syllabus is over (Ghaemi \& Taherian, 2011). The educational system is in need of creative teachers who always incorporate better teaching styles and strategies to be more effective and successful.

Critical thinking has a significant role in higher education and is considered one of the main concerns in mainstream education (Halpern, 1999; Gelder, 2005). Critical thinking has also received a significant attention in second and foreign language learning (Atkinson, 1997) as it is suggested that critical thinking and all its possible effects on language learning are well worth investigating (Nour Mohammadi, 2012). However, most research in this regard has explored the effect of critical thinking on language learners (e.g., Faravani, 2006; Barjesteh \& Vaseghi, 2012) and literature has not paid much attention to language teachers' critical thinking skills and their effects on language teachers' instructional behavior. Therefore, in the current study the relationship between teachers' critical thinking skills 
and vocabulary learning strategy instruction in EFL classes has been investigated. The study seeks answers to the following questions:

1. Is there any relationship between EFL teachers' critical thinking skills and the teaching of vocabulary-learning strategies to their students?

2. Is there any difference between the strength of correlation of critical thinking skills and vocabulary-learning strategy instruction across gender?

\subsection{Critical Thinking}

There is no standard or universally accepted framework to describe or evaluate the construct critical thinking (Myrick, 2002). Literature offers a variety of definitions for critical thinking that differ to some extent (Atkinson, 1997) but have noticeable overlap if one scrutinizes them carefully (Davidson, 1998).

In early definitions, critical thinking was considered as "learning how to ask and answer questions of analysis, synthesis, and evaluation" (Paul, 1985, p. 37) that "encompasses two interconnected processes, namely, identifying and challenging assumptions, and imagining and exploring others" (Brookfield, 1991, p. 229). Critical thinking was also considered to be "the educational cognate of rationality" (Siegel, 1988, p. 32) and the "reasonable and reflective thinking that is focused upon deciding what to believe and do" (Norris \& Ennis, 1989, p. 3). Later more dimensions have been added to the construct and it can be regarded as:

- the scientific method applied by ordinary people to the ordinary world to solve problems (Schafersman, 1991);

- $\quad$ an active and systematic cognitive strategy to examine, evaluate and understand events; make decisions on the basis of sound reasoning and valid evidence (Levy, 1997);

- "reflective thinking involving the evaluation of evidence relevant to a claim so that a sound conclusion can be drawn from the evidence" (Bensley, 1998, p.5); and

- "the use of those cognitive skills or strategies that increase the probability of a desirable outcome,....thinking that is purposeful, reasoned, and goal oriented" (Halpern, 2003, p.6).

Critical thinking is viewed as a process rather than an endpoint or objective (Petress, 2004) that leads to high quality decisions and judgments through analysis, assessment and reformulation of thinking (Giancarlo \& Facione, 2007). Critical thinking has been found to be a tool of inquiry and thus it is very helpful both in education and life as a critical thinker is well-informed, open-minded, flexible, honest, careful in making judgments, skillful in seeking relevant information, and focused in inquiry (Diestler, 2001; Halpern, 2003; Petress, 2004).

While some scholars believe that critical thinking is a part of individuals' genetic make-up, research shows that critical thinking skills are both teachable and learnable (Halpern, 1993). It is also suggested that improving critical thinking skills among special groups of students who want to pursue certain professions such as nursing, law, medicine, and teaching is a paramount concern (Bessick, 2008). When teachers are trained on how to improve their critical thinking skills, they can transform these skills to their students by bringing tasks that need critical thinking and reasoning; and by modeling how to solve problems using critical thinking skills (Beyer, 1987).

\subsection{Critical Thinking and Language Learning}

In the history of educational psychology, close relationships between language and thinking skills have been recognized by theorists and educators (Piaget, 1971; Vygotsky, 1962). Supplemental instruction in critical thinking and abstract reasoning skills are considered as one of the tools that help students to improve learning outcomes at all levels (Stern, 2001).

The importance of promoting higher-order thinking skills in language classrooms has also been the focus of interest among language experts (Chamot, 1995). As students learn critical thinking skills through content course instruction (Fisher, 2001), integrating problem solving activities that need critical thinking in language classes is of vital importance. In this way, how to think rather than what to think is emphasized (Barjesteh \& Vaseghi, 2012) and students are encouraged to participate actively in language classes. Research shows that critical thinking skills are related to English overall proficiency (Rashid \& Hashim, 2008), reading comprehension ability (Fahim, Bagherkazemi, \& Alemi, 2010), vocabulary knowledge (Fahim \& Komijani, 2010), and use of language learning strategies (Nikoopour, Farsani, \& Nasiri, 2011).

It is also evident that teachers play a key role in promoting students' critical thinking skills as "teaching is a complex activity that is influenced by many elements of teacher quality. Teachers and teacher quality is a powerful predictor of student performance" (Ghaemi \& Taherian, 2011, p.9). Therefore, in order to affect students' critical thinking ability, teachers should be trained to improve their thinking skills. Critical thinking instruction helps teachers to make a shift from using mechanical activities to problem solving types in their classes (Bessick, 2008). Possessing critical thinking abilities helps teachers become more successful and effective language teachers (Birjandi \& Bagherkazemi, 2010; Ghaemi \& Taherian, 2011).

\subsection{Vocabulary Learning Strategies}

Learning strategies are defined as "behaviors and thoughts that a learner engages in during learning .... [which are] intended to influence the learner's encoding process" (Weinstein \& Mayer, 1986, cited in Ellis, 1994, p. 315) or "behaviors of a learner that are intended to influence how the learner processes information" (Mayer, 1988, cited in 
Lessard-Clouston, 1997, p. 11). Learning strategies can be employed in all types of teaching and learning such as mathematics, science, history, languages and even in driving both in classroom settings and in more informal and practical learning environments (Lessard-Clouston, 1997).

Since the early 1980s, a string of research has focused on finding the characteristics of a good language learner. The findings of these studies show that good language learners have distinctive characteristics that differentiate them from other learners; the most important one has been reported to be a high level of language learning strategies awareness and use in processing language input and producing the output (Rahimi \& Katal, 2012). Therefore, scholars have tried to specify learning strategies learners use during the process of language learning in reading (Mokhtari \& Reichard, 2002), listening (Vandergrift, Goh, Mareschal, \& Tafaghodtari, 2006), and speaking (Zhang \& Goh, 2006).

In this framework, vocabulary learning strategies are considered as a subcategory of language learning strategies and are defined as

knowledge about the mechanisms (processes, strategies) used in order to learn vocabulary as well as steps or actions taken by students (a) to find out the meaning of unknown words, (b) retain them in long-term memory, (c) recall them at will, and (d) use them in oral or written mode (Catalan, 2003, p. $56)$.

Several types of vocabulary learning strategies have been found to be used by good language learners (e.g., Ahmed, 1989; Sanaoui, 1995). Accordingly, some researchers have proposed classifications of vocabulary learning strategies.

Gu and Johnson's (1996) classification, for instance, consists of seven dimensions and categories of learning strategies including metacognitive regulation (selective attention), guessing (using background knowledge), dictionary (lookingup strategies), note taking (meaning-oriented), rehearsal (using word lists), encoding (association/elaboration), and activation strategies. Another classification for vocabulary learning strategy was proposed by Nation (2001). This taxonomy consists of three main strategies, namely: planning (choosing what to focus on and when to focus on it), sources (finding information about words), and processes (establishing knowledge). Similarly, Lin's (2001) taxonomy of vocabulary learning strategies includes three categories of metacognitive strategies (advanced preparation, selective attention, monitoring, self-management), cognitive strategies (written/verbal repetition, segmentation, phonics application, association, resourcing, predicting), and social-affective strategies (asking for help, cooperation).

A comprehensive inventory of vocabulary learning strategies has been developed by Schmitt (1997). He extracted vocabulary-learning strategies from Oxford's (1990) taxonomy of general language learning strategies and categorized them into two groups of discovery and consolidation strategies. While the former includes those strategies that are used to determine the meaning of new words when encountered for the first time (determination and social strategies), the latter contains those strategies that are used to consolidate meaning when encountered again (cognitive, metacognitive, and memory and social strategies). Social strategies are included in both categories since they can be used for both purposes.

\subsection{Vocabulary Learning Strategies Instruction}

Explicit learning strategy instruction essentially involves the development of students' awareness of the strategies they use, teacher modeling of strategic thinking, student practice with new strategies, student self-evaluation of the strategies used, and practice in transferring strategies to new tasks (Oxford, 1990; Chamot, Barnhardt, El-Dinary, \& Robbins, 1999; Grenfell \& Harris, 1999; Harris, 2003). It is suggested that teachers should implement explicit strategy instruction in their classes instead of teaching strategies in a separate specific course (Chamot, 2004). "Learners need instruction to widen their range of strategies and use them. This training has the role of changing knowledge into skill. It is the independent use of these strategies which is the ultimate goal of strategy instruction" (Bastanfar \& Hashemi, 2010, p. 162).

A number of models for teaching learning strategies in both first and second language contexts have been developed (e.g., Oxford, 1990; Chamot, et al., 1999; Grenfell \& Harris, 1999; Graham \& Harris, 2003; Harris, 2003) and the role of teacher is of paramount importance in all of them. The teacher has the role of a diagnostician who identifies students' current learning strategies (Cohen, 1998); acts as a trainer, model, and coach who models, names, and explains strategies to students (Chamot, 2005); and ultimately evaluates students' use of strategies (Grenfell \& Harris, 1999). Strategy training is a complex process and the way teachers manage strategy instruction guarantees the success of such training (Chamot, 2004).

In spite of the important role teachers play in strategy instruction, very few studies have probed into the role of teachers' characteristics in vocabulary learning strategies instruction.

\section{Method}

\subsection{Participants}

The participants of this study were 90 Iranian EFL teachers who worked in high schools of Tehran in academic year 2012-2013. The sample was selected based on the convenient sampling. Of the sample 64 (71\%) were female and 26 (29\%) were male teachers. Their age ranged from 23 to 56 (mean=32.95).

Fifty-six teachers $(62.2 \%)$ had BA degrees and 34 of them (37.8\%) had MA degrees in TEFL. Their experience of teaching English ranged from 1 to 30 years (mean=10.06). 


\subsection{Instruments}

The data collection instruments were:

\section{California Critical Thinking Skill Test -Form B (CCTST)}

2. Yu-Ling's Inventory of teaching vocabulary-learning strategies to students (Yu-Ling, 2005)

\subsubsection{CCTST}

The Persian version of CCTST- form B was used to assess EFL learners' critical thinking skills as form B of CCTST is suitable to test critical thinking at levels above high school and adults (Facione, 1990).

These 34 items measure five categories of critical thinking ability namely, analysis ( 9 items), evaluation (14 items), inference (11 items), deductive reasoning (16 items), and inductive reasoning (14 items). Each is a multiple choice item designed to be scored dichotomously, with one correct answer and three or four distracters. The reliability of this test using KR20 has been reported to be .78 to .80 (Fasione, 1990).

Khodamorady et al. (2006) have translated this test into Persian and have reported satisfactory construct validity for the scale. They reported reliability of .62 for the whole test and .71 for analysis, .77 for evaluation, .77 for inference, .71 for deductive reasoning, and .71 for inductive reasoning respectively.

The reliability coefficient of CCTST in the current study was calculated using KR20 and turned out to be .69.

\subsubsection{Inventory of teaching vocabulary-learning strategies}

Yu-Ling's inventory of teaching vocabulary learning strategies has 30 items that asks EFL teachers to identify which vocabulary-learning strategy they most frequently teach to their students in their English classes (Yu-ling, 2005).

These items explore the instruction of four types of learning strategies by teachers, namely memory strategies (14 items), cognitive strategies (4 items), metacognitive strategies (2 items), and determination strategies (2 items). Each item is anchored on a 6-point Likert scale from 1 (never) to 6 (always). The items of the scale have been abstracted and adapted mainly from the taxonomy of vocabulary learning strategies compiled by Schmitt (1997).

The reliability of the scale was found to be .89 in the current study.

\subsection{Procedure}

Prior to the study, Yu-Ling's inventory of vocabulary-learning strategies was translated into Persian. It was backtranslated and then checked by three TEFL experts to ensure the clarity of wording. The Persian version of CCTSTForm B (Khodamoradi, et al., 2006) was also checked and the wordings of a few items and distracters were changed to make it more suitable for the context and culture of Iran. Both questionnaires were administered among EFL teachers who worked in high schools of the capital, Tehran. Ninety questionnaires were filled completely and were used for the final data analysis.

\section{Results}

In order to answer research question number 1 and find the relationship between critical thinking skills and teaching vocabulary learning strategies, Pearson Correlation technique was used. As Table 1 shows, strategy instruction is significantly correlated with analysis $(\mathrm{r}=-.27, p<.01)$, inference $(\mathrm{r}=-.23, p<.05)$, and inductive reasoning $(-.3, p<.01)$; but the correlation is not significant considering evaluation $(\mathrm{r}=-.11)$ and deductive reasoning $(\mathrm{r}=-.089)$.

Table 1. Correlation Matrix of Strategy Instruction and Critical Thinking Skills

\begin{tabular}{|c|c|c|c|c|c|c|}
\hline Variables & 1 & 2 & 3 & 4 & 5 & 6 \\
\hline 1. Strategy instruction & 1 & $-.272^{* *}$ & -.112 & $-.226^{*}$ & -.089 & $-.300^{* *}$ \\
\hline 2. Analysis & & 1 & $.242^{*}$ & $.516^{* * *}$ & $.392^{* *}$ & $.639^{* *}$ \\
\hline 3. Evaluation & & & 1 & $.478^{* *}$ & $.861^{* *}$ & $.479^{* *}$ \\
\hline 4. Inference & & & & 1 & $.627^{* *}$ & $.845^{* *}$ \\
\hline 5. Deductive reasoning & & & & & 1 & $.441^{* *}$ \\
\hline 6. Inductive reasoning & & & & & & 1 \\
\hline
\end{tabular}

\footnotetext{
** Correlation is significant at 0.01 level

* Correlation is significant at 0.05 level
}

In order to answer research question number 2 and find the difference between the strength of correlations of critical thinking skills and vocabulary strategy instruction across gender, Pearson Correlation technique and Fisher's $\mathrm{Z}$ were used. 
Table 2. Correlation Matrix of Strategy Instruction and Critical Thinking Skills by Gender

\begin{tabular}{|c|c|c|c|c|c|c|c|}
\hline Variables & Gender & 1 & 2 & 3 & 4 & 5 & 6 \\
\hline \multirow[t]{2}{*}{ 1. Strategy instruction } & Female & 1 & -.150 & -.018 & -.065 & .035 & -.159 \\
\hline & Male & & $-.516^{* *}$ & -.316 & $-.542^{* *}$ & -.377 & $-.541^{* *}$ \\
\hline \multirow[t]{2}{*}{ 2. Analysis } & Female & & 1 & .095 & $.414^{* *}$ & $.283^{*}$ & $.547^{* *}$ \\
\hline & Male & & & $.519^{* *}$ & $.726^{* *}$ & $.633^{* *}$ & $.781^{* *}$ \\
\hline \multirow[t]{2}{*}{ 3. Evaluation } & Female & & & 1 & $.531^{* *}$ & $.850^{* *}$ & $.493^{* *}$ \\
\hline & Male & & & & .374 & $.891^{* *}$ & $.457^{*}$ \\
\hline \multirow[t]{2}{*}{ 4. Inference } & Female & & & & 1 & $.678^{* *}$ & $.819^{* *}$ \\
\hline & Male & & & & & $.517^{* *}$ & $.909^{* *}$ \\
\hline \multirow[t]{2}{*}{ 5. Deductive reasoning } & Female & & & & & 1 & $.439^{* *}$ \\
\hline & Male & & & & & & $.458^{*}$ \\
\hline \multirow[t]{2}{*}{ 6. Inductive reasoning } & Female & & & & & & 1 \\
\hline & Male & & & & & & \\
\hline
\end{tabular}

As the correlation matrix shows, the correlations between critical thinking skills and vocabulary instruction were not statistically significant when female participants were considered; however, the correlations of vocabulary instruction with analysis $(\mathrm{r}=-.516, p<0.01)$, inference $(\mathrm{r}=-.542, p<0.01)$, and inductive reasoning $(\mathrm{r}=-.541, p<0.01)$ were statistically significant among male participants. The result of Fisher's $\mathrm{Z}$ transformation showed that the difference in the correlation between vocabulary learning strategy instruction and inferencing skill for the two groups (males and females) was significant. Table 3 summarizes the value of $Z_{\text {obs }}$ for the differences among correlations.

Table 3. The values of $Z_{\text {obs }}$

\begin{tabular}{lc}
\hline \multicolumn{1}{c}{ Correlations } & $\mathrm{Z}_{\mathrm{obs}}$ \\
\hline Analysis-Strategy instruction & 1.7 \\
\hline Evaluation- Strategy instruction & 1.2 \\
\hline Inference- Strategy instruction & $2.2^{*}$ \\
\hline Deductive reasoning- Strategy instruction & 1.4 \\
\hline Inductive reasoning- Strategy instruction & 1.8 \\
\hline
\end{tabular}

\section{Discussion}

The goal of the present study was investigating the relationship between EFL teachers' critical thinking skills and vocabulary learning strategy instruction. The findings suggest that teaching vocabulary learning strategies has a negative and significant relationship with analysis, inference, and inductive reasoning skills. In other words, those teachers who are more critical thinkers teach language learning strategies less frequently to their students.

The strongest negative correlation was found between strategy teaching and inductive reasoning $(r=-.3)$. It means that those who were better decision makers in the context of uncertainty based on analogies, case studies, prior experience, statistical analyses, simulations, hypotheticals, and familiar circumstances and patterns of behavior chose fewer strategies to teach from the questionnaire that they were asked to fill in. In other words, they evaluate their teaching contexts based on their thinking power and then decide about what to teach.

The next significant correlation was found between strategy instruction and analysis $(r=-.27)$. People with strong analytical skills attend to patterns and details, identify the elements of a situation, and determine how those parts interact. Thus, these teachers think that one size does not fit all and the contextual variables should be specified when strategy instruction is going to be implemented in language classes.

A significant correlation was also found between strategy instruction and inference skill ( $\mathrm{r}=-.22$ ). Generally, people who have high inference skill draw better conclusions from reasons and evidence. Thus, it can be concluded that more critical thinkers are more careful and critical teachers in choosing the strategies from the given questionnaire. They might better analyze the learning condition and their students' abilities and styles, draw better inferences, and as a result teach other techniques/strategies they find more suitable for their students. They might be better reflective teachers and creatively make new strategies they have inferred to work better for vocabulary learning of their students.

Research shows that the low quality of teaching English as a foreign language in Iran is related to five main factors including student-related, teacher-related, school-related, materials-related, and curriculum-related factors (Rahimi \& Nabilou, 2009). As teachers with more critical thinking ability are skillful problem solvers and have exclusive power to identify the problem and choose practical solutions, they may figure out these problems better than teachers with lower critical thinking abilities, and thus avoid strategy instruction. One important challenge Iranian EFL teachers face in their 
classes is the lack of time. As teaching vocabulary strategies needs extensive teaching and long-term plan, critical thinkers may prefer to spend the time of the classroom on using other techniques to help their students get better results. This actually has been supported by research, as critical thinking skills help teachers to be more successful and teach more efficiently (Birjandi \& Bagherkazemi, 2010; Ghaemi \& Taherian, 2011).

Further, it was found that the negative relationship between male teachers' inference skills and vocabulary learning instruction was stronger than that of female teachers. Mixed findings have been reported with respect to the role of gender in critical thinking skills and dispositions (Facione, 1990; Walsh \& Hardy, 1999). While some studies show that gender cannot predict individuals' critical thinking skills, it is suggested that women sometimes feel that critical thinking "is synonymous with 'male logic', a thought process they find adversarial uncomfortable, and alienating" (Browne, Kubasek \& Harris, 1989, p.227). It has also been found that men are more analytical than women (Facione, Sanchez, \& Facione, 1994) and generally score higher in critical thinking skill tests (Leach \& Good, 2011). Thus, it is possible that male teachers intentionally avoided strategy instruction as "strategy training is a complex process which requires committed and informed teachers who spend an extended period of time working with learners" (Bastanfar \& Hashemi, 2010, p. 161). In other words, male teachers with higher critical thinking ability were more aware of the contextual constraints and challenges of teaching English and thus preferred to use teaching techniques that work better in their context of teaching, instead of strategy instruction.

\section{Conclusions}

The findings of the present study revealed that vocabulary-learning strategy instruction was inversely related to inductive reasoning, analysis, and inference skills. It was also found that male teachers with higher inference skills used less vocabulary-learning strategies in their classes.

The results show that critical thinking skills can give teachers deep insights into the impact of contextual constraints on their teaching effectiveness. Teachers with higher critical thinking abilities are more careful about choosing teaching techniques and materials that can guarantee effective teaching and better learning outcome. Critical thinking skills also help teachers to utilize more creative thinking and become more productive and innovative in their classes. As creative teachers have a wide repertoire of routines and strategies, they are more flexible and can switch between different styles and modes of teaching during the lesson (Richards, 2013). Thus, they adapt and modify their teaching to better match the learners' needs.

The findings of the study highlight the importance of promoting teachers' higher order thinking to apply critical evaluation that is purposeful, reasoned, and goal oriented. In this way teachers will become more concerned about the type of teaching methodologies or instructional materials they are forced to use and move towards applying a negotiated syllabus in their teaching.

\section{References}

Ahmed, M. (1989). Vocabulary Learning Strategies. In P. Meara (Ed.), Beyond Words (pp. 3-14). London: CILT. Atkinson, D. (1997). A critical approach to critical thinking in TESOL. TESOL Quarterly, 31, 79-95.

Barjesteh, H., \& Vaseghi, R. (2012). Critical thinking: A reading strategy in developing English reading comprehension performance. Sheikhbahaee EFL Journal, 1, 21-34.

Bastanfar, A., \& Hashemi, T. (2010). Vocabulary learning strategies and ELT materials: A study of the extent to which VLS research informs local coursebooks in Iran. International Education Studies, 3, 158-166.

Bensley, D.A. (1998). Critical thinking in psychology: A unified skills approach. Pacific Grove, CA: Brooks/Cole. Bessick, S. C. (2008). Improved critical thinking skills as a result of direct instruction and their relationship to academic achievement. Unpublished PhD Dissertation. US: Indiana University of Pennsylvania.

Birjandi, P., \& Bagherkazemi, M. (2010). The relationship between Iranian EFL teachers' critical thinking ability and their professional success. English Language Teaching, 3, 135-145.

Brookfield, S. D. (1991). Developing Critical Thinkers: Challenging adults to explore alternative ways of thinking and acting. US: Open University Press.

Browne, M., Kubasek, K., \& Harris, A. (1989). The challenge to critical thinking posed by gender-related and learning styles research. Professional and Organizational Development Network in Higher Education, 1, 225-234.

Beyer, B.K. (1987). Practical strategies for the teaching of thinking. US: Allyn and Bacon, Inc.

Calderhead, J. (1987). Exploring teachers' thinking. UK: Cassel.

Campbell, L. M. (2000). The unspoken dialogue: Beliefs about intelligence, students, and instruction held by a sample of teachers familiar with the theory of multiple intelligences. Unpublished PhD Dissertation. US: The Fielding Institute.

Catalan, R. M. J. (2003). Sex differences in L2 vocabulary learning strategies. International Journal of Applied Linguistics, 13, 54-77. 
Center for Critical Thinking. (1996). A brief history of the idea of critical thinking.

http://www.criticalthinking.org/aboutCT/briefhistoryCT.shtml

Chaffee, J. (1985). Thinking critically. Boston: Houghton Miftlin Company.

Chamot, A.U. (1995). Learning strategies and listening comprehension. In D. Mendelsohn \& J. Rubin (Eds.). A guide for the teaching of second language listening (pp. 13-30). US: Dominie Press.

Chamot, A.U., Barnhardt, S., El-Dinary, P.B., \& Robbins, J. (1999). The Learning Strategies Handbook. US: Longman.

Chamot, A. (2004). Issues in language learning strategy research and teaching. Electronic Journal of Foreign Language Teaching, 1, 14-26.

Chamot, A. (2005). Language learning strategy instruction: Current issues and research. Annual Review of Applied Linguistics, 25, 112-130.

Cohen, A.D., (Ed.). (1998). Strategies in learning and using a second language. UK: Longman.

Davidson, B.W. (1998). A case for critical thinking in the English language classroom. TESOL Quarterly, 32, 119123.

Diestler, S. (2001). Becoming a critical thinker: A user friendly manual (3rd ed.). US: Prentice Hall.

Ellis, R. (1994). The study of second language acquisition. Oxford: Oxford University Press.

Ennis, R. (2011). Critical thinking: Reflection and perspective Part I. Inquiry: Critical Thinking across the Disciplines, 26, 1, 4-18.

Facione, P.A. (1990). The California Critical Thinking Skills Test-College Level: Factors predictive of CT skills (Report No. 2). US: California Academic Press.

Facione, P.A., Sanchez, C. A., \& Facione, N.C. (1994). Are college students disposed to think? US: California Academic Press.

Fahim, M., \& Komijani, A. (2010). Critical thinking ability, L2 vocabulary knowledge, and L2 vocabulary learning strategies. Journal of English Studies, 1, 23-38.

Fahim, M., Bagherkazemi, M., \& Alemi, M. (2010). The relationship between test takers' critical thinking ability and their performance on the reading section of TOEFL. Journal of Language Teaching and Research, 1, 830-837 Faravani (2006). Portfolio and critical thinking. Unpublished MA Thesis. Iran: Ferdowsi University.

Gelder, T. V. (2005). Teaching critical thinking: Some lessons from cognitive science. College Teaching, 53, 41-48. Ghaemi, H., Taherian, R. (2011). The role of critical thinking in EFL teachers' teaching success. MJAL, 3, 8-22. Giancarlo, C. A., \& Facione, P.A. (2007). A look across four years at the disposition toward critical thinking among undergraduate students. Journal of General Education, 5, 29-55.

Grenfell, M., \& Harris, V. (1999). Modern languages and learning strategies: In theory and practice. UK: Routledge.

Gu, P. Y., \& Johnson, R. K. (1996).Vocabulary learning strategies and language learning outcomes. Language Learning, 46, 643-679

Halpern, D. F. (1999). Teaching for critical thinking: Helping college students develop the skills and dispositions of a critical thinker. New Directions for Teaching and Learning, 80, 69-74.

Halpern, D. F. (2003). Thought and knowledge: An introduction to critical thinking (4 $4^{\text {th }}$ ed.). US: Lawrence Erlbaum Associates.

Harris, V. (2003). Adapting classroom-based strategy instruction to a distance learning context. TESL-EJ, 7. http://www-writing.berkeley.edu/TESL-EJ/ej26/a1.html

Huitt, W. (1998). Critical thinking: An overview. Educational Psychology Interactive. US: Valdosta State University.

Khodamorady, K., Saidozakerin, M., Alavi Majd, H., Yaghmaei, F., \& Shahabi, M. (2005). Translation and psychometric characteristics of California Critical Thinking Skill Test -Form B. Journal of the Faculty of Nursing and Midwifery, 55, 12-19.

Leach, B., \& Good, D. (2011). Critical thinking skills as related to university students' gender and academic discipline. International Journal of Humanities and Social Science, 1, 100-106. 
Lessard-Clauston, M. (1997). Language learning strategies: An overview for L2 teachers. The Internet TESL

Journal, 3. http://iteslj.org/Articles/Lessard-Clouston Strategy.html

Levy, D. A. (1997). Tools of critical thinking: Metathoughts for psychology. US: Allyn and Bacon.

Lin, L. (2001). Taiwanese children's EFL vocabulary learning strategies. MA Thesis. Taiwan: Chin-Hwa University.

Mokhtari, K., \& Reichard, C. (2002).Assessing students' metacognitive awareness of reading strategies. Journal of

Educational Psychology, 94, 249-259.

Myrick, F. (2002). Preceptorship and critical thinking in nursing education. Journal of Nursing Education, 41, 154

164.

Nation, I.S.P. (2001). Learning vocabulary in another language. Cambridge: Cambridge University Press.

Nikoopour, J., Amini Farsani, M., \& Nasiri, M. (2011). On the relationship between critical thinking and language learning strategies among Iranian EFL learners. Journal of Technology \& Education, 5, 195-200.

Norris, S. P., \& Ennis, R. (1989). Evaluating critical thinking. US: Critical Thinking Press and Software.

Nour Mohammadi, E. (2012). The relationship between critical thinking ability and reading strategies used by Iranian EFL learners. English Language Teaching, 5, 192-201.

O'Malley, J., \& Chamot, A. (1990). Learning strategies in second language acquisition. Cambridge: Cambridge University Press.

Oxford, R. L. (1990). Language learning strategies: What every teacher should know. US: Heinle \& Heinle.

Petress, K. (2004). Critical thinking: An extended definition. Education, 124, 461-466.

Piaget, J. (1971). Genetic epistemology. US: W. W. Norton \& Company.

Pithers, R. T., \& Soden, R. (2000). Critical Thinking in education: A review. Educational Research, 42, 237-249

Rahimi, M., \& Nabilou, Z. (2009). Globalization and EFL curriculum reform in Iran: Challenges and opportunities. Journal of Technology of Education, 3, 115-124. Available online: www.sid.ir.

Rahimi, M., \& Katal, M. (2012). The role of metacognitive listening strategies awareness and podcast-use readiness in using podcasting for learning English as a foreign language. Computers in Human Behavior, 28, 1153-1161.

Rashid, R. A., \& Hashim, R. A. (2008). The Relationship between critical thinking and language proficiency of Malaysian and undergraduates. Proceeding of the EDU-COM 2008 International Conference, Symposia and Campus Events, 19-21. Australia: Edith Cowan University.

Richards, J. C. (2013). Creativity in language teaching. Plenary address given at the Summer Institute for English Teacher of Creativity and Discovery in Teaching University Writing. Hong Kong: City University of Hong Kong.

http://www.professorjackrichards.com/wp-content/uploads/Creativity-in-Language-Teaching.pdf

Richards, J. C., \& Farrell, T. S. (2005). Professional development for language teachers: Strategies for teacher learning. Cambridge: Cambridge University Press.

Sanaoui, R. (1995). Adult learner's approaches learning vocabulary in second languages. The Modern Language Journal, 79, 15-28.

Schafersman (1991). An introduction to critical thinking. www.freeenquiry/criticalthinking.html

Schmit, N., 1997. Vocabulary learning strategies. In N. Schmitt and M. McCarthy, (Eds). Vocabulary: Description, acquisition and pedagogy (pp. 199-227). Cambridge: Cambridge University Press.

Siegel, H. (1988). Educating reason: Rationality, critical thinking and education. US: Routledge \& Metheun.

Stern, S. (2001). Learning assistance centers: Helping students through. ERIC Clearinghouse for Community Colleges, No. ED 455901.

Vandergrift, L., Goh, C., Mareschal, C., \& Tafaghodtari, M. H. (2006). The metacognitive awareness listening questionnaire (MALQ): Development and validation. Language Learning, 56, 431-462.

Vygotsky, L. (1962). Thought and language. US: The MIT Press.

Walsh, C. M., \& Hardy, R. (1999). Dispositional differences in critical thinking related to gender and academic major. Journal of Nursing Education, 38, 149-155.

Yu-ling, L. (2005). Teaching vocabulary learning strategies awareness, beliefs, and practices: A survey of Taiwanese EFL senior high-school teachers. MA Thesis. UK: University of Essex

Zhang, D., \& Goh, C. (2006). Strategy knowledge and perceived strategy use: Singaporean students' awareness of listening and speaking strategies. Language Awareness, 15, 199-221. 